\title{
Human adiponectin inhibits cell growth and induces apoptosis in human endometrial carcinoma cells, HEC-1-A and RL95-2
}

\author{
Li Cong ${ }^{1,2}$, Jessica Gasser ${ }^{1}$, Jessica Zhao ${ }^{1}$, Baofeng Yang ${ }^{2}$, Fanghong Li ${ }^{1}$ \\ and Allan Z Zhao ${ }^{1}$
}

${ }^{1}$ Department of Cell Biology and Physiology, University of Pittsburgh, S-326, BSTWR, 3500 Terrace Street, Pittsburgh, Pennsylvania 15261, USA

${ }^{2}$ Department of Endocrinology and Metabolism, The Second Affiliated Hospital, Harbin Medical University, Harbin, 150086 China

(Requests for offprints should be addressed to A Z Zhao; Email: azhao @ pitt.edu)

\begin{abstract}
Obesity is one of the well-established risk factors for endometrial cancer. Recent clinical studies have demonstrated that circulating adiponectin concentrations are inversely correlated with the incidence of endometrial carcinoma. Such epidemiological findings are consistent with the paradoxical observations that adiponectin levels are reduced in obesity. This study investigated the direct effects of adiponectin on two endometrial carcinoma cell lines, HEC-1-A and RL95-2. These cell lines express both variants of adiponectin receptors, adipo-R1 and adipo-R2. Adiponectin treatment leads to suppression of cell proliferation in both cell types, which is primarily due to the significant increase of cell populations at $\mathrm{G}_{1} / \mathrm{G}_{0}$-phase and to the induction of apoptosis. The inhibition of growth in these two cell lines appears to be mediated by different signaling pathways. Although adiponectin treatment markedly increases the phosphorylation (Thr172) of AMP-activated protein kinase $\alpha$ in both HEC-1-A and RL95-2 within 30 min, prolonged exposure ( $48 \mathrm{~h}$ ) leads to inactivation of Akt as well as reduction of cyclin D1 protein expression in HEC-1-A cells. In contrast, similar treatment of RL95-2 cells with adiponectin, while having no effects on Akt activity and cyclin D1 expression, causes a decrease in cyclin E2 expression and the activity of mitogen-activated kinase (p42/44). We conclude that adiponectin exerts direct anti-proliferative effects on HEC-1-A and RL95-2 cells by inducing cell cycle arrest and apoptosis. Depending on the genotypes of the endometrial cancer cells, the inhibitory effects of adiponectin are associated with the reduction of different pro-growth regulators of cell cycle and signaling proteins. Our study thus provides a cellular mechanism underlying the linkages between endometrial cancer and obesity.
\end{abstract}

Endocrine-Related Cancer (2007) 14 713-720

\section{Introduction}

Besides being a serious risk factor for type 2 diabetes and cardiovascular diseases (Kahn \& Flier 2000), obesity is also found to be associated with the development and progression of several types of cancer (Calle \& Thun 2004), among which endometrial carcinoma shows arguably the strongest correlation with obesity (Akhmedkhanov et al. 2001). Although genetic mutations (such as in phosphatase tensin homolog, PTEN) are well recognized for their roles in the pathogenesis of endometrial cancer (Akhmedkhanov et al. 2001, Zhu et al. 2001), other adipocytesderived factors have also contributed to the regulation of cancer cell growth (Housa et al. 2006). For example, both insulin-like growth factor-I (IGF-I) and estrone can be synthesized in and released by adipocytes, both of which have been established for their stimulatory roles in cell growth (Dougherty \& Sanders 2005, Laviola et al. 2007).

As a member of adipokine family, adiponectin is synthesized and secreted almost exclusively by the adipose tissue (Scherer et al. 1995, Kadowaki \& Yamauchi 2005). It is abundantly present in the blood and participates in the regulation of glucose and lipid homeostasis (Kadowaki \& Yamauchi 2005). Paradoxically, circulating levels of adiponectin are decreased, rather than increased, in obesity (Scherer et al. 1995, 
Weyer et al. 2001, Kadowaki \& Yamauchi 2005). The reduction of blood concentrations of adiponectin is not only closely related to disease states such as type 2 diabetes and cardiovascular diseases in human obesity (Weyer et al. 2001, Ronchi et al. 2004), but also implicated in cancer development. Recent clinical studies involving several independent cohorts have demonstrated that plasma concentrations of adiponectin are inversely correlated with the risk of several types of cancer, including breast cancer (Chen et al. 2006), colorectal cancer (Otake et al. 2005), and endometrial carcinoma (Petridou et al. 2003, Cust et al. 2007). These clinical observations raise the possibility that adiponectin itself might directly act as an inhibitory factor on tumor growth. Consistent with this hypothesis, several cellular studies find that adiponectin can elicit anti-proliferative effects in breast cancer and prostate cancer cells (Bub et al. 2006, Dieudonne et al. 2006, Korner et al. 2007, Wang et al. 2006).

So far, there have been two canonical signaling pathways identified for adiponectin, one of which is through the activation of AMP-activated protein kinase (AMPK), a highly conserved serine/threonine protein kinase (Yamauchi et al. 2002). The other pathway is through elevation of intracellular cAMP and activation of cAMP-dependent protein kinase A (PKA; Ouchi et al. 2000). Both of these pathways are known to exert anti-proliferative effects on various cell types (Chen et al. 1998, Luo et al. 2005). For example, activation of AMPK is known to suppress cell growth and cause apoptosis in human cancer cells such as prostate cancer cells (Luo et al. 2005) and glioma cells (Rattan et al. 2005). Similarly, the cAMP/PKA pathway has been shown to inhibit cell growth in several cell types such as vascular smooth muscle cells (Indolfi et al. 1997) and leukemia B-cells (Jiang et al. 1996). This study was designed to investigate the hypothesis that adiponectin can inhibit cell proliferation and/or induce apoptosis in two different human endometrial cancer cell lines, HEC-1-A (containing wild-type PTEN activity) and RL95-2 (deficient in PTEN activity; Zhu et al. 2001). In addition, we also explored the potential signaling mechanisms underlying such effects of adiponectin.

\section{Materials and methods}

\section{Reagents}

Recombinant human adiponectin was purchased from BioVendor Laboratory Medicine (Brno, Czech Republic) and R\&D Systems (Minneapolis, MN, USA). Though not necessarily fully equivalent to the circulating forms in human blood, the full-length recombinant human adiponectin protein, after reconstituted, forms multimeric structures (described in BioVendor product data sheet).

\section{Cell culture}

Human endometrial cancer cell lines, HEC-1-A and RL95-2 cells, were obtained from American Type Culture Collection (Manassas, VA, USA). HEC-1-A and RL95-2 cells were grown in McCoy's 5A modified medium and DMEM/F12 respectively supplemented with $10 \%$ fetal bovine serum, penicillin (100 UI/ml), and streptomycin $(100 \mathrm{mg} / \mathrm{ml})$ in a humidified atmosphere of $95 \%$ air and $5 \% \mathrm{CO}_{2}$ at $37^{\circ} \mathrm{C}$.

\section{Adiponectin receptor expression}

Total RNA was isolated from HEC-1-A and RL95-2 cells with TRIZOL reagent (Invitrogen), and was subsequently treated with DNase I (Ambion, Austin, TX, USA) to remove contaminating genomic DNA. The RT-PCRs were performed using a kit from Promega Corp. The reactions were carried out with the following cycles: $48^{\circ} \mathrm{C}, 45 \mathrm{~min}(1$ cycle $) ; 94{ }^{\circ} \mathrm{C}$, 2 min $\left(1\right.$ cycle); $94{ }^{\circ} \mathrm{C}, 30 \mathrm{~s}, 57^{\circ} \mathrm{C}, 30 \mathrm{~s}, 68^{\circ} \mathrm{C}, 2 \mathrm{~min}$ (40 cycles); and $68^{\circ} \mathrm{C}, 7 \mathrm{~min}$ ( 1 cycle). The sequences of the primers are listed below. Human adiponectin R1: 5'-TTCTTCCTCATGGCTGTGATGT-3'; 5'-AGTGGACAAAGGCTGCTGCCA- $3^{\prime}$. Human adiponectin R2: 5' - ATGAACGAGCCAACAGAAAACCGA-3'; 5'-CGGTGTCCATGCAAGAGGAAGTCA-3'. After amplification, the PCR mixture was separated on $2.0 \%$ agarose gel and stained with ethidium bromide.

\section{Cell count}

HEC-1-A and RL95-2 cells were plated in 12-well culture plates. Before performing the experiments, cells were serum-deprived overnight and then human recombinant adiponectin $(10,20$, and $40 \mu \mathrm{g} / \mathrm{ml})$ was added to the cells. Medium and the reagent were replaced once at $24 \mathrm{~h}$. Cells were harvested and counted using a hemocytometer $48 \mathrm{~h}$ after adiponectin treatment.

\section{Analysis of cell cycle and apoptosis}

After HEC-1-A and RL95-2 cells were incubated in serum-free medium overnight, cells were treated with adiponectin (20 and $40 \mu \mathrm{g} / \mathrm{ml}$ ) for $48 \mathrm{~h}$ (medium was changed and fresh adiponectin was added daily). Both floating and trypsinized adherent cells were collected and rinsed with PBS. For cell cycle analysis, the cells were fixed in $70 \%$ ethanol at $4{ }^{\circ} \mathrm{C}$ overnight. Before 
performing flow cytometry assays, the cells were washed with PBS twice, and resuspended in $1 \mathrm{ml}$ PBS containing $0.1 \mathrm{mg}$ RNase (DNase free) for $30 \mathrm{~min}$ at room temperature. The cells were then resuspended with PBS containing $10 \mu \mathrm{g} / \mathrm{ml}$ propidium iodide (PI; Sigma) and incubated for $15 \mathrm{~min}$ in the darkness at room temperature. The DNA content was analyzed using a BD FACStar flow cytometer and the percentages of different phases of cell cycle were determined using a ModFit program (BD Biosciences, San Jose, CA, USA).

Detection of apoptotic cells was performed using Annexin-V-FITC kit (BD Biosciences, San Jose, CA, USA) and PI staining. In this assay, single positive populations are considered early apoptotic (annexin-V positive/PI negative) or necrotic cells (annexin-V negative/PI positive), whereas double positive (annexin-V positive/PI positive) cells are thought to be in a late stage of apoptosis. The staining was performed according to the manual of the manufacture. Briefly, the cells were incubated in the binding buffer (2.5 mM CaCl $2,150 \mathrm{mM} \mathrm{NaCl}, 10 \mathrm{mM}$ HEPES, $\mathrm{pH}$ 7.4) containing annexin-V-FITC and PI for $15 \mathrm{~min}$ at $20^{\circ} \mathrm{C}$. Early and late apoptotic cells were quantified using the flow cytometer.

\section{Western blot analysis}

HEC-1-A and RL95-2 cells were seeded into 12-well plates. Before performing the experiment, the medium was changed to DMEM/F12 without phenol red and fetal bovine serum. After $2 \mathrm{~h}$ of serum deprivation, the cells were treated with adiponectin $(20$ and $40 \mu \mathrm{g} / \mathrm{ml})$ for $30 \mathrm{~min}$ or $48 \mathrm{~h}$. Whole cell extract was prepared from HEC-1-A and RL95-2 cells using cell lysis buffer (50 mM NaF, $150 \mathrm{mM} \mathrm{NaCl}, 10 \mathrm{mM}$ sodium pyrophosphate, $2 \mathrm{mM}$ EDTA, $0.1 \%$ Triton X-100, and a cocktail mixture of protease inhibitors (Roche Diagnostics)). Whole cell protein extract was separated on $12 \%$ SDS-PAGE and transferred to nitrocellulose membrane (Bio-Rad). After the incubation in 5\% BSA (for the detection of phospho-specific proteins) or $5 \%$ milk solution for $1 \mathrm{~h}$, the membranes were incubated with primary antibodies overnight at $4{ }^{\circ} \mathrm{C}$ according to manufacturer's suggestions. The primary antibodies against phospho-AMPK $\alpha$ (Thr172), AMPK, phospho-Akt (Ser473), Akt, phospho-MAPK (p42/44; Thr202/Tyr204), MAPK (p42/44), cyclin D1, cyclin E2, and $\beta$-actin were from Cell Signaling Technology. Visualization of protein bands was achieved using a standard enhanced chemiluminescent reaction.

\section{Statistical analysis}

Data are presented as the mean \pm s.D. Statistical analysis was performed using one-way ANOVA. A value of $P<0.05$ was considered statistically significant.

\section{Results}

\section{Expression of adiponectin receptors in HEC-1-A and RL95-2 cells}

Previous studies have identified two types of adiponectin receptors, adipo-R1 and adipo-R2 (Yamauchi et al. 2003). Using RT-PCR assays with oligonucleotide primers specific for the human forms of two receptors, we found that both adipo-R1 and adipo-R2 were expressed in HEC-1-A and RL95-2 cells, as indicated by the appearance of the expected DNA bands in the RT-PCRs (Fig. 1).

\section{Suppression of endometrial cancer cell prolifer- ation by adiponectin}

Due to their own ability of secreting growth factors, such as transforming growth factor $\alpha$ (TGF- $\alpha$ ) and IGF-I, HEC-1-A and RL95-2 cells can still maintain the ability of growth in the absence of serum (Reynolds et al. 1998). Thus, we applied human adiponectin to these cultured cells in the absence of serum. The concentrations of adiponectin used in our studies were within or near the physiological ranges observed in humans (Weyer et al. 2001). Treatment of the cultured HEC-1-A or RL95-2 cells with human adiponectin resulted in dosage-dependent suppressive effects on

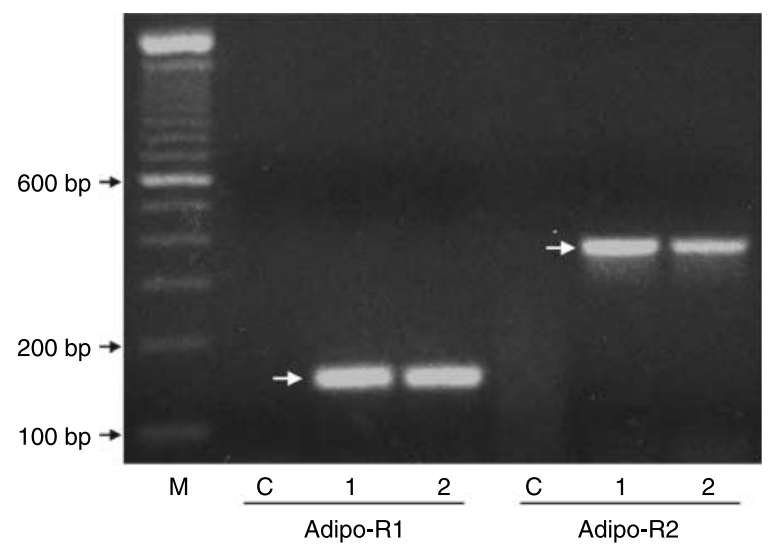

Figure 1 The expression of adiponectin receptors in HEC-1-A and RL95-2 cells. The mRNA expression of adiponectin-R1 (adipo-R1) and adiponectin-R2 (adipo-R2) was detected in both HEC-1-A and RL95-2 cells. The expected fragments specific to adipo-R1 and adipo-R2 were 150 and 377 bps respectively and were marked with solid arrows. $\mathrm{M}$, marker; $\mathrm{C}, \mathrm{H}_{2} \mathrm{O}$ control; 1 , HEC-1-A cells; 2, RL95-2 cells. 


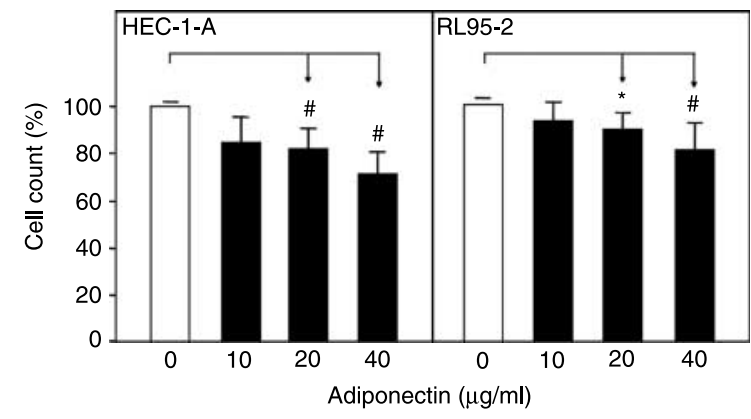

Figure 2 The effects of adiponectin on cell proliferation in HEC1-A and RL95-2 cells. HEC-1-A and RL95-2 cells were serumdeprived overnight, and then incubated with adiponectin $(10,20$ and $40 \mu \mathrm{g} / \mathrm{ml}$ ) for $48 \mathrm{~h}$. At the end of incubation, the attached cells were collected for cell counts. The values were shown as mean \pm s.D. Data were the averages of the triple measurements in an experiment. The experiments were repeated thrice. The symbols '*' and '\#' indicate statistical difference at $P<0.05$, $P<0.01$ respectively between adiponectin-treated groups and untreated controls.

cell proliferation (Fig. 2) at the end of 48-h incubation. At $20 \mu \mathrm{g} / \mathrm{ml}$, human adiponectin inhibited the growth of HEC-1-A and RL95-2 cell by $18.1(P<0.01)$ and $10.7 \%(P<0.05)$ respectively (Fig. 2$)$. At the highest dosage ( $40 \mu \mathrm{g} / \mathrm{ml}$ ), adiponectin produced nearly 30 and $20 \%$ reduction of cell counts in HEC-1-A and RL95-2 cells respectively $(P<0.01$ for both; Fig. 2$)$.

To further explore the anti-proliferative actions of human adiponectin, we analyzed the changes in cell cycle using flow cytometry analysis. Accordingly, at 20 and $40 \mu \mathrm{g} / \mathrm{ml}$, human adiponectin increased the percentage of HEC-1-A cells in $\mathrm{G}_{1} / \mathrm{G}_{0}$-phase from 31.7 to $35.8 \% \quad(P<0.05)$ and $42.1 \% \quad(P<0.01)$ respectively (Table 1); concomitant with these changes, the percentage of HEC-1-A cells in S-phase was decreased from 48.9 to $45.9 \%$ $(P<0.05)$ and $40.3 \% \quad(P<0.01)$ respectively (Table 1). Similar results were also observed when we treated RL95-2 cells with adiponectin (Table 1). Thus, the suppressive effects of adiponectin on endometrial cancer cell growth were associated with significant increase of cell populations at $\mathrm{G}_{1} / \mathrm{G}_{0}$-phase and a concomitant decrease of the treated cells at S-phase.

\section{Induction of apoptosis by human adiponectin}

As an additional step to evaluate the inhibitory effects of human adiponectin on endometrial cancer cell growth, we examined the state of apoptosis of the cells after adiponectin treatment using flow cytometry assays. We found that there was a significant increase in the percentage of apoptotic cells as revealed by the annexin-V staining positive patterns (Fig. 3). This appears to be the case whether we were examining both early apoptotic events (annexin- $\mathrm{V}$ positive only) and late apoptotic events (both annexin- $\mathrm{V}$ and propidium (PI) positive; Fig. 3). For instance, at $40 \mu \mathrm{g} / \mathrm{ml}$, adiponectin caused more than five-fold of increase in early apoptosis (5.6 vs $1.1 \%$ control, $P<0.01$ ) and more than fourfold of increase in total (including early and late) apoptosis ( 7.9 vs $1.8 \%$ control, $P<0.01)$ in HEC-1-A cells after $48 \mathrm{~h}$ of incubation (Fig. 3). Treatment of RL95-2 cells with the same dosage of adiponectin produced similar increases in apoptosis (Fig. 3). We need to emphasize that the inhibitory nature of adiponectin on cell growth (including the induction of apoptosis) was unlikely due to some nonspecific toxicity resided in the reagent itself since a parallel treatment of a rat pancreatic $\beta$-cell line, INS-1, did not lead to suppression of cell growth (data not shown).

\section{The signaling pathways induced by adiponectin in HEC-1-A and RL95-2 cells}

To understand the potential molecular mechanisms underlying the anti-proliferative effects of human adiponectin on endometrial cancer cells, we evaluated some of the signaling events induced by adiponectin. We found that AMPK could be rapidly activated by

Table 1 Flow cytometry analysis of cell cycle in HEC-1-A and RL95-2 cells

\begin{tabular}{|c|c|c|c|c|c|c|}
\hline & \multicolumn{3}{|c|}{ HEC-1-A } & \multicolumn{3}{|c|}{ RL95-2 } \\
\hline & C & AN $(20 \mu \mathrm{g} / \mathrm{ml})$ & AN $(40 \mu \mathrm{g} / \mathrm{ml})$ & $\mathrm{C}$ & AN $(20 \mu \mathrm{g} / \mathrm{ml})$ & AN $(40 \mu \mathrm{g} / \mathrm{ml})$ \\
\hline $\mathrm{G}_{1} / \mathrm{G}_{0}(\%)$ & $31.7 \pm 0.6$ & $35.8 \pm 1.4^{*}$ & $42.1 \pm 0.1^{\dagger}$ & $54.5 \pm 1.4$ & $59.6 \pm 1.3^{\dagger}$ & $61.4 \pm 0.3^{\dagger}$ \\
\hline S (\%) & $48.9 \pm 0.1$ & $45.9 \pm 2.0^{*}$ & $40.3 \pm 0.9^{\dagger}$ & $27.2 \pm 2.7$ & $22.1 \pm 1.5^{\dagger}$ & $19.8 \pm 0.5^{\dagger}$ \\
\hline G2/M (\%) & $19.3 \pm 0.5$ & $18.3 \pm 0.3$ & $17.6 \pm 0.9$ & $18.3 \pm 1.6$ & $18.3 \pm 0.1$ & $18.8 \pm 0.7$ \\
\hline
\end{tabular}

HEC-1-A and RL95-2 cells were incubated with adiponectin (20 and $40 \mu \mathrm{g} / \mathrm{ml}$ ) for $48 \mathrm{~h}$. At the end of incubation, the cells were collected for FACS analysis (see Materials and methods). The values were shown as mean \pm s.D. Data were the averages of triple measurements in an experiment. The experiments were repeated thrice. AN, adiponectin. The symbols '*' and ' ${ }^{+}$' indicate statistical significance at $P<0.05, P<0.01$ (compared with untreated controls) respectively based on one-way ANOVA. 


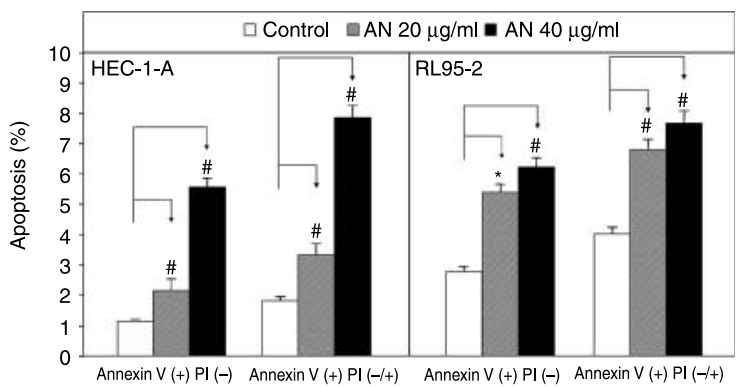

Figure 3 Induction of apoptosis by adiponectin in HEC-1-A and RL95-2 cells. HEC-1-A and RL95-2 cells were serumdeprived overnight before treated with adiponectin (20 and $40 \mu \mathrm{g} / \mathrm{ml}$ ) for $48 \mathrm{~h}$. Apoptotic cells were detected with annexin- $V$ and propidium iodide staining, and quantified using a BD FACStar flow cytometer. The values were shown as mean \pm s.D. Data were the averages of triple measurements in an experiment. The experiments were repeated thrice. The symbols '*' and '\#'indicate statistical significance at $P<0.05, P<0.01$ respectively between adiponectin groups and untreated controls.

adiponectin treatment within $30 \mathrm{~min}$ in both HEC-1-A and RL95-2 cells, which was evident by the increase of phosphorylation (at Thr172) on the $\alpha$-subunit of AMPK (Fig. 4A). The activation of AMPK by adiponectin occurred only at early time points $(30 \mathrm{~min}$ to $1 \mathrm{~h}$, Supplementary Figure 1, which can be viewed online at http://erc.endocrinology-journals.org/supplemental/), a signaling event likely to be needed for triggering the subsequent anti-growth actions of adiponectin.

A

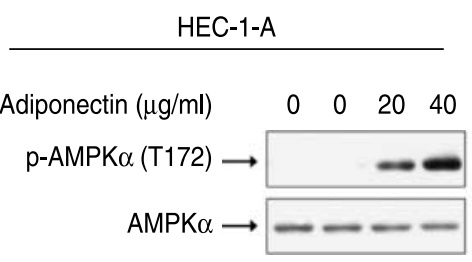

B

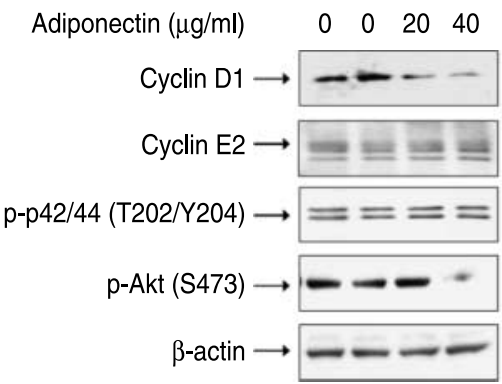

Interestingly, in the longer treatment $(48 \mathrm{~h})$ with adiponectin, the signaling events diverged in these two cell lines. Accordingly, in HEC-1-A cells, adiponectin treatment caused sharp reductions in cyclin D1 expression and in the level of activated Akt $(\sim 70 \%$ decrease for cyclin D1 and $>80 \%$ decrease for activated Akt at $40 \mu \mathrm{g} / \mathrm{ml}$ of adiponectin; Fig. 4B). During the same time frame of adiponectin treatment, the expression of cyclin E2 and the level of activated MAPK (p42/44) were unchanged in the HEC-1-A cells. In contrast, the expression of cyclin D1 and the level of activated Akt did not change following the treatment with adiponectin in RL95-2 cells (Fig. 4B), whereas the levels of cyclin E2 as well as the activated MAPK (p42/44) were suppressed by $\sim 50 \%$ (Fig. 4B). The protein expression levels of the total Akt and MAPK (p42/44) were not altered by adiponectin treatment in both cell types (Supplementary Figure 1). Thus, the inhibitory effects of adiponectin on endometrial cancer cell proliferation were associated with the distinct reductions of several key regulatory components of cell cycle as well as pro-growth kinases, depending on the genotypes of the cancer cell lines.

\section{Discussion}

In this study, we find that human adiponectin inhibits the proliferation of two different types of human endometrial cancer cells, HEC-1-A and RL95-2, and that the negative impact of adiponectin on cell growth
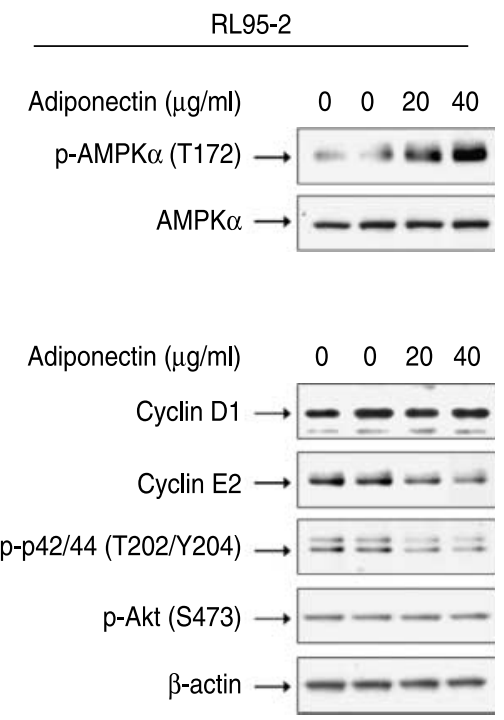

Figure 4 The effects of adiponectin on pro-growth signaling pathways in HEC-1-A and RL95-2 cells. HEC-1-A and RL95-2 cells were deprived of serum for $2 \mathrm{~h}$ before addition of adiponectin $(20$ and $40 \mu \mathrm{g} / \mathrm{ml})$. (A) At the end of 30-min incubation, the cells were extracted in a lysis buffer for western analysis of phospho-AMPK $\alpha$ (Thr172) and total AMPK $\alpha$. (B) At the end of 48-h incubation, the cells were extracted for western analysis of cyclins D1 and E2 protein expression. The levels of activated Akt and MAPK (p42/44) were analyzed using corresponding phospho-specific antibodies and western blot assays (see Materials and methods). The examples shown here represent the results of one of the two independent experiments. 
is primarily due to the increase of cell populations arrested at $\mathrm{G}_{1} / \mathrm{G}_{0}$-phase as well as to the induction of apoptosis. Owing to their own ability to secrete growth factors, such as TGF- $\alpha$ and IGF-I (Reynolds et al. 1998), both HEC-1-A and RL95-2 cells can maintain aggressive proliferation even in the absence of serum in the culture. Currently, it is not yet clear which of these growth factors' actions adiponectin can oppose. Previous studies have reported the negative influence of adiponectin on platelet-derived growth factor- and fibroblast growth factor-stimulated proliferation of vascular smooth muscle cells (Cinti et al. 2005). In addition, our recent study has also found that human adiponectin can attenuate IGF-I-stimulated growth of breast cancer cells, MCF7 (unpublished observations). However, future studies are required to reveal the potential interactions between human adiponectin and the growth factors that are stimulatory to the growth of human endometrial cancer cells.

A major genetic difference between HEC-1-A and RL95-2 cells lies in the gene of PTEN with HEC-1-A containing the wild-type, and RL95-2 completely deficient in, PTEN activity (Zhu et al. 2001). PTEN is a tumor suppressor gene whose deficiency has been linked to several types of cancer including endometrial carcinoma (Tashiro et al. 1997). The lipid phosphatase activity resided in PTEN is critical in reducing the phosphorylated forms of phosphatidylinositol (PI) and the subsequent blockade of the PI3-kinase (PI3K) signaling pathway (Cantley \& Neel 1999). Null mutations in PTEN will lead to constitutive activation of PI3K and Akt (Zhu et al. 2001). Interestingly, in the two cell lines we have tested, adiponectin has drastically different inhibitory effects on the activities of Akt and MAPK, both of which are known for their potent mitogenic actions (Johnson \& Lapadat 2002, Toker \& Yoeli-Lerner 2006). Particularly, adiponectin was able to suppress Akt activity in HEC-1-A cells, but not in RL95-2 cells. Although, based on these initial observations, it is tempting to speculate that adiponectin acts either on upstream of PTEN or through a pathway independent of PTEN, the mechanisms by which adiponectin influences endometrial cancer growth in the presence or absence of PTEN remain to be defined. In addition, the changes in Akt or MAPK activities did not occur until $48 \mathrm{~h}$ after adiponectin treatment when significant suppression of cell growth already happened (Supplementary Figure 1). Thus, further studies are required to define if the changes of these two pro-growth kinases are coincidental with or required for adiponectin-induced inhibition of cell growth.
In our study, we also find that adiponectin can reduce the expression of cyclin D1 and cyclin E2 in HEC-1-A and RL95-2 cells respectively. Cell cycle progression is a tightly controlled series of events that are positively regulated by cyclin-dependent kinases and their regulatory subunits, cyclins (Murray 2004). Cyclin D1 is a key regulatory element during cell cycle progression from $\mathrm{G}_{1}$ - to $S$-phase (Murray 2004). It has been reported that overexpression of cyclin D1, not only existed in endometrial cancer but also correlated with its poor prognosis (Nikaido et al. 1996). Similarly, one of the molecular markers of endometrial cancer cells is the elevated level of cyclin E2 (Oshita et al. 2002), which also helps to propel the progression from $\mathrm{G}_{1}$ - to S-phase. Thus, adiponectin-induced reduction of cyclin D1 or cyclin E2 expression is potentially a critical step for the suppression of endometrial cancer cell growth.

AMPK cascade is considered a sensor of cellular energy status and can be activated by stress, such as glucose deprivation, oxidative stress, and hypoxia (Yamauchi et al. 2002). Activation of AMPK can inhibit cancer cells proliferation and induce apoptosis (Rattan et al. 2005). Thus, adiponectin-induced activation of AMPK is likely an important signaling mechanism underlying the increased apoptosis and suppressed growth in both HEC-1-A and RL95-2 cells. Such observation is also consistent with previous findings that adiponectin can induce apoptosis in cultured breast cancer and endothelial cells (Brakenhielm et al. 2004, Dieudonne et al. 2006). However, further studies are required to delineate the pathways leading from the activation of AMPK to the changes of expression in cell cycle machinery, particularly cyclins D1 and E2.

Obesity is a serious risk factor for endometrial carcinoma (Akhmedkhanov et al. 2001). Although estrogen is one of the well-known 'culprits' in the development of endometrial cancer (Akhmedkhanov et al. 2001), the roles of other adipocytes-derived factors are still being defined. Adiponectin belongs to one of the adipokine family members, and its circulating concentrations are reduced in obesity despite the fact that it is exclusively synthesized in the fat cells (Weyer et al. 2001). Although adiponectin is traditionally known for its critical functions in regulating glucose and lipid metabolism as well as in maintaining cardiovascular health (Scherer et al. 1995, Kadowaki \& Yamauchi 2005), recent clinical evidence also points to a strong inverse correlation between the plasma concentrations of adiponectin and the risk of endometrial cancer (Petridou et al. 2003, Dal Maso et al. 2004, Cust et al. 2007). The results of our cellular 
studies, though to be confirmed in tumor models in vivo, are entirely consistent with the abovementioned clinical observations, and suggest that circulating adiponectin exerts a direct negative influence on the growth of endometrial cancer cells. To our knowledge, such cellular observations have not been reported. The deficiency in adiponectin may thus serve as one of the molecular linkages between obesity and endometrial carcinoma.

\section{Acknowledgements}

We would like to thank Drs Yani Zhao and Binfeng Lu for their generous technical help in FACS analysis. We would like to thank Dr Xiaonan Hou for her critical reading of the manuscript. This work is supported in part by a grant from National Institute of Health (1RO1DK064383) and a Research Award from American Diabetes Association (7-06-RA-173) to A $\mathrm{Z} \mathrm{Z}$, and a Pilot and Feasibility grant to $\mathrm{F} \mathrm{H} \mathrm{L}$ (5P30DK046204) from the Obesity and Nutrition Research Center at the University of Pittsburgh. There is no conflict of interest that would prejudice the impartiality of this work.

\section{References}

Akhmedkhanov A, Zeleniuch-Jacquotte A \& Toniolo P 2001 Role of exogenous and endogenous hormones in endometrial cancer: review of the evidence and research perspectives. Annals of New York Academy of Sciences 943 296-315.

Brakenhielm E, Veitonmaki N, Cao R, Kihara S, Matsuzawa Y, Zhivotovsky B, Funahashi T \& Cao Y 2004 Adiponectininduced antiangiogenesis and antitumor activity involve caspase-mediated endothelial cell apoptosis. PNAS $\mathbf{1 0 1}$ 2476-2481.

Bub JD, Miyazaki T \& Iwamoto Y 2006 Adiponectin as a growth inhibitor in prostate cancer cells. Biochemical and Biophysisical Research Communications 340 1158-1166.

Calle EE \& Thun MJ 2004 Obesity and cancer. Oncogene 23 6365-6378.

Cantley LC \& Neel BG 1999 New insights into tumor suppression: PTEN suppresses tumor formation by restraining the phosphoinositide 3-kinase/AKT pathway. PNAS 96 4240-4245.

Chen TC, Hinton DR, Zidovetzki R \& Hofman FM 1998 Up-regulation of the cAMP/PKA pathway inhibits proliferation, induces differentiation, and leads to apoptosis in malignant gliomas. Laboratory Investigation 78 165-174.

Chen DC, Chung YF, Yeh YT, Chaung HC, Kuo FC, Fu OY, Chen HY, Hou MF \& Yuan SS 2006 Serum adiponectin and leptin levels in Taiwanese breast cancer patients. Cancer Letters 237 109-114.
Cinti S, Mitchell G, Barbatelli G, Murano I, Ceresi E, Faloia E, Wang S, Fortier M, Greenberg AS \& Obin MS 2005 Adipocyte death defines macrophage localization and function in adipose tissue of obese mice and humans. Journal of Lipid Research 46 2347-2355.

Cust AE, Kaaks R, Friedenreich C, Bonnet F, Laville M, Lukanova A, Rinaldi S, Dossus L, Slimani N, Lundin E et al. 2007 Plasma adiponectin levels and endometrial cancer risk in pre- and postmenopausal women. Journal of Clinical Endocrinology and Metabolism. 92 255-263.

Dal Maso L, Augustin LS, Karalis A, Talamini R, Franceschi S, Trichopoulos D, Mantzoros CS \& La Vecchia C 2004 Circulating adiponectin and endometrial cancer risk. Journal of Clinical Endocrinology and Metabolism. 89 1160-1163.

Dieudonne MN, Bussiere M, Dos Santos E, Leneveu MC, Giudicelli Y \& Pecquery R 2006 Adiponectin mediates antiproliferative and apoptotic responses in human MCF7 breast cancer cells. Biochemical and Biophysisical Research Communications 345 271-279.

Dougherty DC \& Sanders MM 2005 Estrogen action: revitalization of the chick oviduct model. Trends in Endocrinology and Metabolism 16 414-419.

Housa D, Housova J, Vernerova Z \& Haluzik M 2006 Adipocytokines and cancer. Physiological Research 55 233-244.

Indolfi C, Avvedimento EV, Di Lorenzo E, Esposito G, Rapacciuolo A, Giuliano P, Grieco D, Cavuto L, Stingone AM, Ciullo I et al. 1997 Activation of cAMP-PKA signaling in vivo inhibits smooth muscle cell proliferation induced by vascular injury. Nature Medicine 3 775-779.

Jiang X, Li J, Paskind M \& Epstein PM 1996 Inhibition of calmodulin-dependent phosphodiesterase induces apoptosis in human leukemic cells. PNAS 93 11236-11241.

Johnson GL \& Lapadat R 2002 Mitogen-activated protein kinase pathways mediated by ERK, JNK, and p38 protein kinases. Science 298 1911-1912.

Kadowaki T \& Yamauchi T 2005 Adiponectin and adiponectin receptors. Endocrine Reviews 26 439-451.

Kahn BB \& Flier JS 2000 Obesity and insulin resistance. Journal of Clinical Investigations 106 473-481.

Korner A, Pazaitou-Panayiotou K, Kelesidis T, Kelesidis I, Williams CJ, Kaprara A, Bullen J, Neuwirth A, Tseleni S \& Mitsiades N 2007 Total and high molecular weight adiponectin in breast cancer: in vitro and in vivo studies. Journal of Clinical Endocrinology 92 1041-1048.

Laviola L, Natalicchio A \& Giorgino F 2007 The igf-I signaling pathway. Current Pharmaceutical Design 13 663-669.

Luo Z, Saha AK, Xiang X \& Ruderman NB 2005 AMPK, the metabolic syndrome and cancer. Trends in Pharmacological Sciences 26 69-76.

Murray AW 2004 Recycling the cell cycle: cyclins revisited. Cell 116 221-234.

Nikaido T, Li SF, Shiozawa T \& Fujii S 1996 Coabnormal expression of cyclin D1 and p53 protein in human uterine endometrial carcinomas. Cancer 78 1248-1253. 
Oshita T, Shigemasa K, Nagai N \& Ohama K 2002 p27, Cyclin $\mathrm{E}$, and CDK2 expression in normal and cancerous endometrium. International Journal Oncology 21 737-743.

Otake S, Takeda H, Suzuki Y, Fukui T, Watanabe S, Ishihama K, Saito T, Togashi H, Nakamura T, Matsuzawa Y et al. 2005 Association of visceral fat accumulation and plasma adiponectin with colorectal adenoma: evidence for participation of insulin resistance. Clinical Cancer Research 11 3642-3646.

Ouchi N, Kihara S, Arita Y, Okamoto Y, Maeda K, Kuriyama H, Hotta K, Nishida M, Takahashi M, Muraguchi M et al. 2000 Adiponectin, an adipocyte-derived plasma protein, inhibits endothelial NF-kappaB signaling through a cAMP-dependent pathway. Circulation 102 1296-1301.

Petridou E, Mantzoros C, Dessypris N, Koukoulomatis P, Addy C, Voulgaris Z, Chrousos G \& Trichopoulos D 2003 Plasma adiponectin concentrations in relation to endometrial cancer: a case-control study in Greece. Journal of Clinical Endocrinology and Metabolism. 88 993-997.

Rattan R, Giri S, Singh AK \& Singh I 2005 5-Aminoimidazole-4-carboxamide-1-beta-D-ribofuranoside inhibits cancer cell proliferation in vitro and in vivo via AMPactivated protein kinase. Journal of Biological Chemistry 280 39582-39593.

Reynolds RK, Hu C \& Baker VV 1998 Transforming growth factor-alpha and insulin-like growth factor-I, but not epidermal growth factor, elicit autocrine stimulation of mitogenesis in endometrial cancer cell lines. Gynecologic Oncology 70 202-209.

Ronchi CL, Corbetta S, Cappiello V, Morpurgo PS, Giavoli C, Beck-Peccoz P, Arosio M \& Spada A 2004 Circulating adiponectin levels and cardiovascular risk factors in acromegalic patients. European Journal of Endocrinology 150 663-669.
Scherer PE, Williams S, Fogliano M, Baldini G \& Lodish HF 1995 A novel serum protein similar to $\mathrm{C} 1 \mathrm{q}$, produced exclusively in adipocytes. Journal of Biological Chemistry 270 26746-26749.

Tashiro H, Blazes MS, Wu R, Cho KR, Bose S, Wang SI, Li J, Parsons R \& Ellenson LH 1997 Mutations in PTEN are frequent in endometrial carcinoma but rare in other common gynecological malignancies. Cancer Research 57 3935-3940.

Toker A \& Yoeli-Lerner M 2006 Akt signaling and cancer: surviving but not moving on. Cancer Research 66 3963-3966.

Wang Y, Lam JB, Lam KS, Liu J, Lam MC, Hoo RL, Wu D, Cooper GJ \& Xu A 2006 Adiponectin modulates the glycogen synthase kinase-3beta/beta-catenin signaling pathway and attenuates mammary tumorigenesis of MDA-MB-231 cells in nude mice. Cancer Research 66 11462-11470.

Weyer C, Funahashi T, Tanaka S, Hotta K, Matsuzawa Y, Pratley RE \& Tataranni PA 2001 Hypoadiponectinemia in obesity and type 2 diabetes: close association with insulin resistance and hyperinsulinemia. Journal of Clinical Endocrinology and Metabolism. 86 1930-1935.

Yamauchi T, Kamon J, Minokoshi Y, Ito Y, Waki H, Uchida S, Yamashita S, Noda M, Kita S, Ueki K et al. 2002 Adiponectin stimulates glucose utilization and fatty-acid oxidation by activating AMP-activated protein kinase. Nature Medicine 8 1288-1295.

Yamauchi T, Kamon J, Ito Y, Tsuchida A, Yokomizo T, Kita $\mathrm{S}$, Sugiyama T, Miyagishi M, Hara K, Tsunoda M et al. 2003 Cloning of adiponectin receptors that mediate antidiabetic metabolic effects. Nature 423 762-769.

Zhu X, Kwon CH, Schlosshauer PW, Ellenson LH \& Baker SJ 2001 PTEN induces G(1) cell cycle arrest and decreases cyclin D3 levels in endometrial carcinoma cells. Cancer Research 61 4569-4575. 